\title{
Changes in the Physico-Chemical Properties of Human Kidney Cell Membranes during the Cancer Transformation
}

\author{
Barbara Szachowicz-Petelska1 ${ }^{*}$, Izabela Dobrzyńska1, Zbigniew A. Figaszewski ${ }^{1,2}$, \\ Jacek Kudelski ${ }^{3}$ \\ ${ }^{1}$ Institute of Chemistry, University in Białystok, Białystok, Poland \\ ${ }^{2}$ Laboratory of Electrochemical Power Sources, Faculty of Chemistry, University of Warsaw, Warsaw, Poland \\ ${ }^{3}$ Clinical Department of Urology, Medical University of Białystok, Białystok, Poland \\ Email: ${ }^{*}$ basia@uwb.edu.pl
}

Received 2 April 2014; revised 7 May 2014; accepted 15 May 2014

Copyright (C) 2014 by authors and Scientific Research Publishing Inc.

This work is licensed under the Creative Commons Attribution International License (CC BY).

http://creativecommons.org/licenses/by/4.0/

(c) (i) Open Access

\begin{abstract}
Kidney tissue is particularly susceptible to reactive oxygen species attack which leads to development of cancer. During oxidative stress, membrane lipids and proteins are major targets of reactive oxygen species (ROS). This work is focused on changes of phospholipids, proteins content and electric charge that occur in cell membranes of kidney cancer of pT3 stage, grade G3 and with metastasis. Qualitative and quantitative phospholipid composition and the presence of integral membrane proteins were determined by high-performance liquid chromatography. Electrophoresis was used to determine the surface charge density of the human kidney cell membrane. It was shown that the process of cancer transformation was accompanied by an increase phospholipid levels and altered the level of integral proteins as determined by decrease phenylalanine, tyrosine, cysteine and arginine. Moreover, the process of cancer transformation significantly enhanced changes in the surface charge density of the human kidney cell membrane. Cell membrane structure and function are modified by neoplasm lesion.
\end{abstract}

\section{Keywords}

Phospholipids, Proteins, Electric Charge, Human Kidney

\section{Introduction}

Cell membrane is an integral part of an alive cell and it plays an essential role in life processes. The most im-

"Corresponding author.

How to cite this paper: Szachowicz-Petelska, B., Dobrzyńska, I., Figaszewski, Z.A. and Kudelski, J. (2014) Changes in the Physico-Chemical Properties of Human Kidney Cell Membranes during the Cancer Transformation. Advances in Biological Chemistry, 4, 223-231. http://dx.doi.org/10.4236/abc.2014.44027 
portant properties of a biological membrane are its electric charge and its potential drop between the membrane and surrounding solution. Electric properties of the membrane are determined by acid-base and complex formation equilibria of membrane and solution components [1]. Most membrane components—phospholipids and proteins-are involved in those equilibria.

Immune cell activation and tumour growth result in an increased rate of "de novo" synthesis and turnover of membrane phospholipids [2]. It is well established that both the amount and type of fat consumed in the diet influence the lipid composition of immune and tumour cell membranes [3]. Changes in membrane structural characteristics in mammalian cells can change the activity of proteins that serve as ion channels, transporters, receptors, signal transducers or enzymes [4]. The phenomena connected with changes in cell membranes are suspected to play an important role during the cancer transformation. Our previous experiments demonstrated that the cell membrane and the function are modified during cancer transformation. It is reflected by changes in the amount of phospholipids, proteins and free fatty acids in human colorectal cancer cell membrane [2] [5]-[7].

Tumour cells produce and excrete to blood numerous substances which are present in the cell itself in trace amounts only. They are called tumour biomarkers. Their physico-chemical properties are diverse and they are classed to several groups: cancer-phoetal antigens, carcinogenic antigens, proteins, cell metabolism product, cell growth factors, hormones, enzymes and isoenzymes [5]. They are transported to blood circulation system across the cell membrane. Therefore, the estimation of the state of the tumour cells membrane is likely to be essential in the studies on tumours biology.

Therefore, the examining of electric charge may reveal a lot of information about the renal cell membrane. The work is focused on changes of phospholipids and proteins content and electric charge that occur in cell membranes of renal cancer.

\section{Materials and Methods}

Kidney tissue samples were obtained from 8 patients (6 men and 2 women) who underwent nephrectomy because of renal cancer. Tumor staging system consists of 4 TNM stages-lower number is related to better clinical prognosis. Our study included only low stage renal cancers classified histopathologically as renal clear cell cancer in G3 grade in Fuhrman scale and pT3 stage. The patients had lymph nodes $(\mathrm{N}+)$ involved at the time of diagnosis. The age of patients ranged from 38 to 78 years old. Tumor samples with healthy renal tissue were collected immediately after tumor removal.

These human studies were in concordance with ethical standards of 1975 Declaration of Helsinki and its latest revision in 2004 and approved by the Ethics Committee of Medical University of Bialystok. All the participants gave their informed consent before inclusion in the study.

\subsection{Phospholipid Isolation and Analysis by High-Performance Liquid Chromatography (HPLC)}

Kidney cell membranes were prepared by differential centrifugation method as described by [8] [9]. Phospholipids were extracted in chloroform-methanol as described by Folch [10]. Normal phase (NP)-HPLC separations were done using a Merck HPLC system equipped with a pump, an ultraviolet (UV) detector, an analog interface module (D-6000 A) and System Manager software. Phospholipids were separated using a silica gel column, with an acetonitryle-methanol-phosphoric acid (85\%) mixture (130:5:1.5 volume ratio) by isocratic elution at $1 \mathrm{~mL} /$ sec flow rate and $214 \mathrm{~nm}$ wavelength [6].

\subsection{Extraction of Membrane Proteins and Analysis by High-Performance Liquid Chromatography (HPLC)}

The cell membranes were rinsed with $\mathrm{NaOH}$ prior to solubilization in $30 \mathrm{ml}$ buffer containing $20 \mathrm{mM}$ Tris/HCl $(\mathrm{pH} 7.4)$ and $1 \%$ Triton $\mathrm{X}-100$ at $4^{\circ} \mathrm{C}$. The suspension was centrifuged at $1000 \times \mathrm{g}$ for $10 \mathrm{~min}$. The supernatant was incubated at $32^{\circ} \mathrm{C}$ for $2 \mathrm{~h}$ and was then dialyzed against distilled water and evaporated until dry [11] The membrane protein extract was hydrolysed by trypsin, at an enzyme:substrate ratio of 1:25 [12]. The reaction mixtures were incubated at $37^{\circ} \mathrm{C}$ for $1 \mathrm{~h}$. Hydrolysis was stopped by the addition of PMSF. Following hydrolysis, the peptides were separated by HPLC on a LichroCART RP-18 column 100A (5 $\mu \mathrm{m}, 250 \times 4.0 \mathrm{~mm}$ ) equilibrated with solvent A [0.1\% trifluoroacetic acid (TFA) in $\mathrm{H}_{2} \mathrm{O}$ ] and eluted with a linear gradient of $20 \%$ to $100 \%$ 
solvent B (0.1\% TFA in acetonitrile) using a flow rate of $1 \mathrm{~mL} / \mathrm{min}$ [7]. A typical separation of the peptide mixture containing integral renal membrane proteins is provided in Figure 1. The amino acid compositions of isolated peptides (6.2 min; $8.2 \mathrm{~min}$; $9.1 \mathrm{~min} ; 11.7 \mathrm{~min} ; 12.6 \mathrm{~min} ; 14 \mathrm{~min} ; 17.1 \mathrm{~min} ; 27.4 \mathrm{~min} ; 28.9 \mathrm{~min} ; 30.7 \mathrm{~min}$ ) were hydrolyzed as described previously [7]. The amino acid separation was performed on a Lichrosorb $\mathrm{NH}_{2}$ column 100A ( $5 \mu \mathrm{m}, 250 \times 4.6 \mathrm{~mm})$. The mobile phase consisted of solvents $\mathrm{A}\left(0.01 \mathrm{M} \mathrm{KH}_{2} \mathrm{PO}_{4}, \mathrm{pH} 4.3\right)$ and $\mathrm{B}$ (a 500:70 mixture of acetonitrile/water). All separations were performed with a 5\% to 50\% gradient of solvent A using a flow rate of $1 \mathrm{ml} / \mathrm{min}$. All of the peptides originated from different groups that consistently contained the following four amino acids: Phe, Tyr, Cys and Arg (Figure 2).

\subsection{Electrochemical Methods}

In order to determine surface charge density of cell membrane, kidney tissue from human was exposed to trypsin action. Received cells were put into the measuring vessel, then electrophoretic mobility on dependent $\mathrm{pH}$ was measured by using Zetasizer Nano ZS apparatus (MALVERN INSTRUMENTS).

The surface charge density has been determined using equation: $\sigma=\eta \mathrm{u} / \mathrm{d}$; where $\mathrm{u}$ is the electrophoretic mobility, $\eta$ in the viscosity of the solution and $\mathrm{d}$ is the diffuse layer thickness [13]. The diffuse layer thickness was determined from the formula $d=\sqrt{\frac{\varepsilon \cdot \varepsilon_{0} \cdot R \cdot T}{2 \cdot F^{2} \cdot I}}$, where $R$ is the gas constant, $T$ is the temperature, $F$ is the Faraday number, $I$ is the ionic strength of $0.9 \% \mathrm{NaCl}$, and $\varepsilon$ and $\varepsilon_{0}$-are the relative and absolute permittivities of the medium [14].

Acidic $\left(\mathrm{C}_{\mathrm{TA}}\right)$ and basic $\left(\mathrm{C}_{\mathrm{TB}}\right)$ functional group concentrations and their average association constants with hydrogen $\left(\mathrm{K}_{\mathrm{AH}}\right)$ or hydroxyl $\left(\mathrm{K}_{\mathrm{BOH}}\right)$ ions were determined as described previously [15].

\subsection{Statistical Methods}

The data obtained in this study are expressed as mean \pm SD. The data were analysed using Wilcoxon MatchedPairs Signed-Ranks Test (from standard statistical program SPSS 8.0 PL) for comparisons between control and cancer samples. The values of $\mathrm{p}<0.05$ were considered significant.

\section{Results}

\subsection{The Phospholipid Composition of Kidney Cell Membranes during Cancer Transformation}

Figure 3 shows that the levels of phospholipids increased significantly during cancer transformation in the cell membrane. We worked out an average of 8 patients because the changes observed in patients 1 - 8 proved to be similar. The content of the individual phospholipids: phosphatidylinositol (PI), phosphatidylserine (PS), phosphatidylethanoloamine (PE), and phosphatidylcholine (PC) increased by about $60 \%, 36 \%$, 47\%, and $45 \%$, respectively.

\subsection{The Integral Membrane Proteins of Kidney Cell Membranes during Cancer Transformation}

Figure 4 shows that the levels of integral membrane proteins decreased significantly during cancer transformation in the cell membrane. About a 30\% decrease in integral membrane protein levels was observed in the patients at pT3 stage, G3 grade with metastasis with respect to the unaffected cells.

Figure 5 shows changes in peptide content after hydrolysis of proteins isolated from cell membranes from the control and tumour. We worked out an average of 8 patients because the changes observed in patients 1-8 proved to be similar. Cancer transformation caused an decrease in peptide levels relative to the unmodified cells. The peptide contents at the following selected retention times [in min.]: 6.2; 8.2; 9.1; 11.7; 12.6; 14; 17.1; 27.4; 28.9; 30.7 decreased approximately: 23\%; 25\%; 24\%; 27\%; 19\%; 25\%; 48\%; 12\%; 21\% and 24\%, respectively. The levels of the amino acids Phe, Cys, Tyr and Arg were determined for individual peptides following kidney membrane protein hydrolysis. The cancer tissues showed a decrease in the amount of individual amino acids relative to the control. We also worked out an average of 8 patients because the changes observed in patients 1 8 proved to be similar (Table 1 ). 


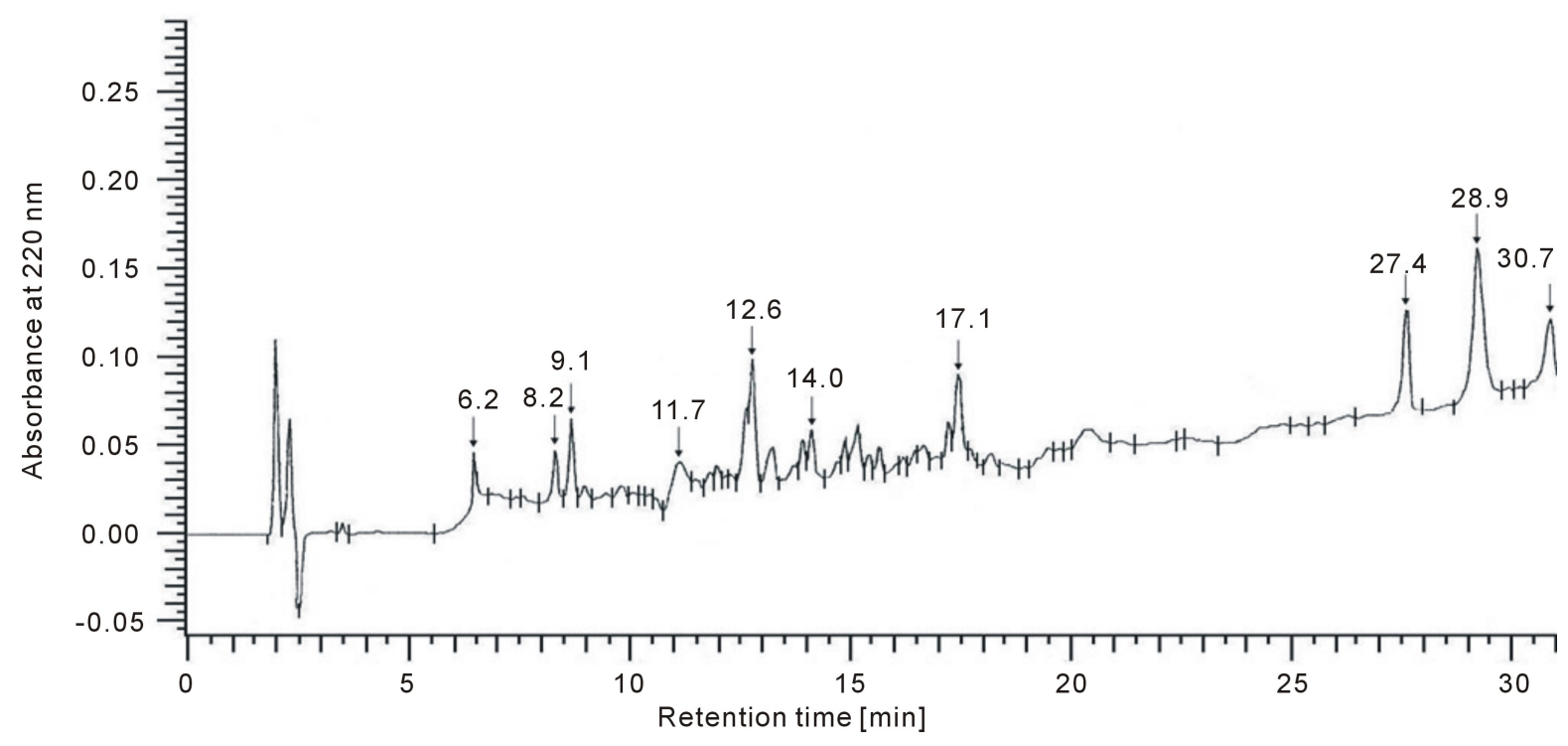

Figure 1. A example separation of peptides from tissue integral membrane proteins (UV detected at $220 \mathrm{~nm}$ ).

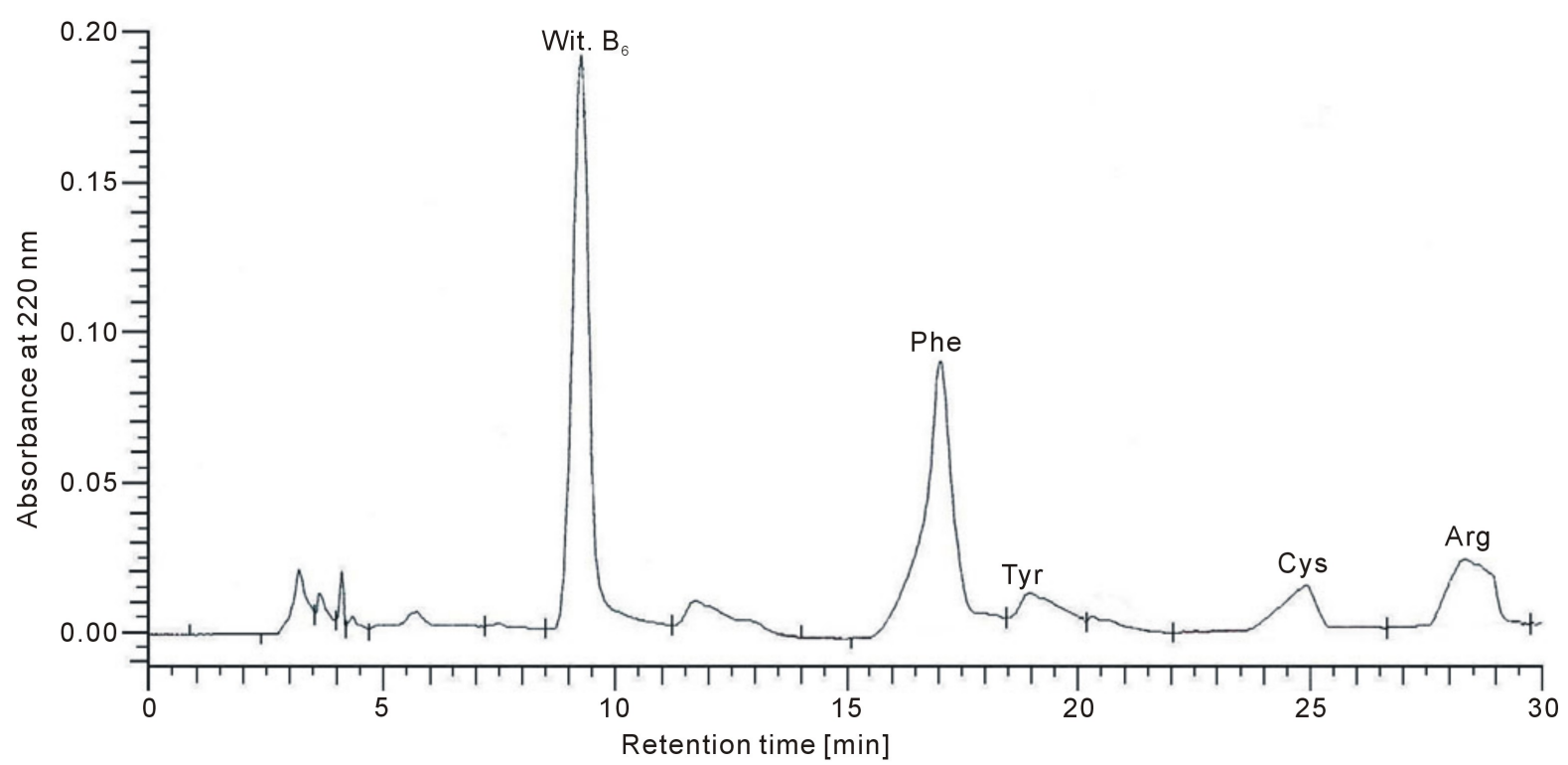

Figure 2. Chromatogram for the amino acids Phe, Tyr, Cys and Arg, which occurred in the all of the peptides for control and tumour group after hydrolysis of kidney cell membrane protein isolates (UV detected at $200 \mathrm{~nm}$ ).

\subsection{The Electric Properties of Kidney Cell Membranes during Cancer Transformation}

Surface charge density dependences on $\mathrm{pH}$ of normal and renal cancer cell membrane are similarly shaped (Figure 6). There is an increase in positive surface charge density of the cells at low $\mathrm{pH}$ values until a plateau is reached. At high $\mathrm{pH}$ values, the negative charge of the cells also increases reaching a plateau. Overall, an increase in negative charge at low $\mathrm{pH}$ values as well as in positive charge et high ones is observed in human renal cancer cells compared to unaffected cells.

The surface fraction occupied by phospholipids and proteins as well as the surface concentration of acidic groups $\left(\mathrm{C}_{\mathrm{TA}}\right)$ and the surface concentration of basic groups $\left(\mathrm{C}_{\mathrm{TB}}\right)$ parameters of human kidney cell membrane unmodified and of the membrane modified by neoplasm lesion are presented in Table 2. An increase in acid and basic groups surface concentration was observed in the above mentioned patients with respect to unmodified 


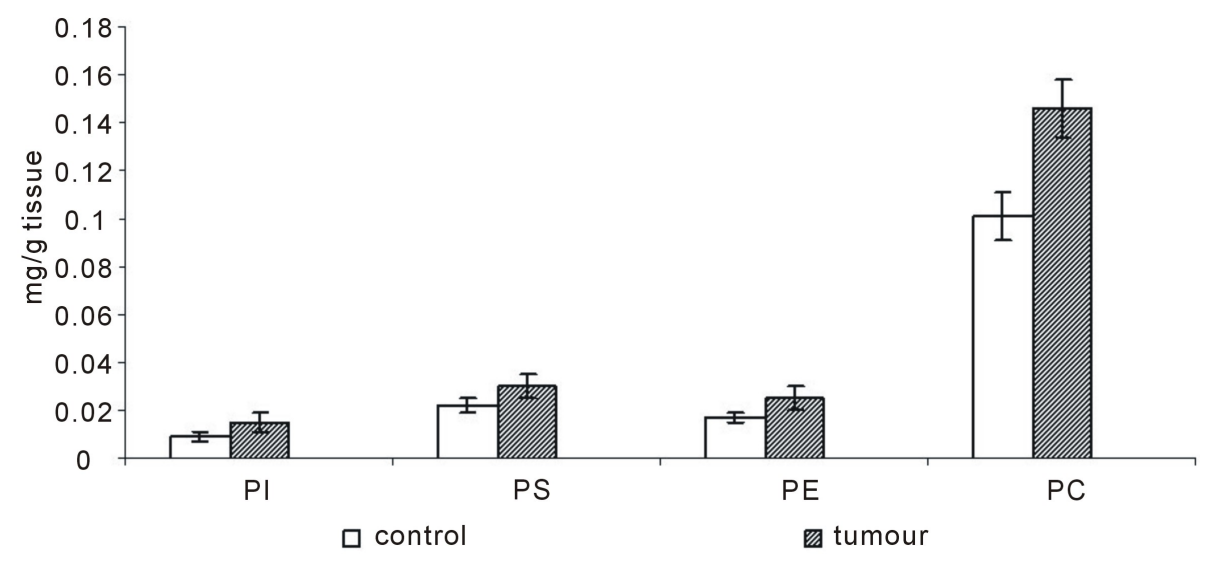

Figure 3. Content of phospholipids of cell membranes in human renal cancer of pT3 stage, G3 grade with metastasis. Statistically significant differences for $\mathrm{p}<0.05$. ${ }^{\mathrm{x}}$ In comparison with control.

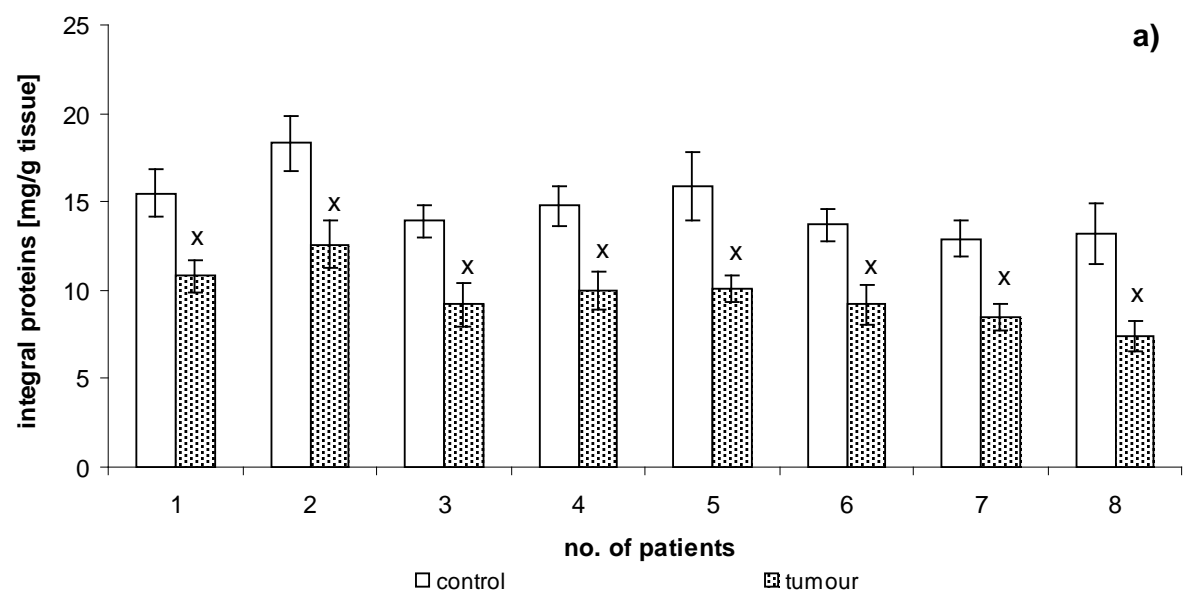

Figure 4. Content of integral membrane proteins of cell membranes in human renal cancer of pT3 stage, G3 grade with metastasis, calculated per $1 \mathrm{~g}$ tissue (a) or per $1 \mathrm{mg}$ phospholipids (b). Statistically significant differences for $\mathrm{p}<0.05$. ${ }^{\mathrm{x}}$ In comparison with control.

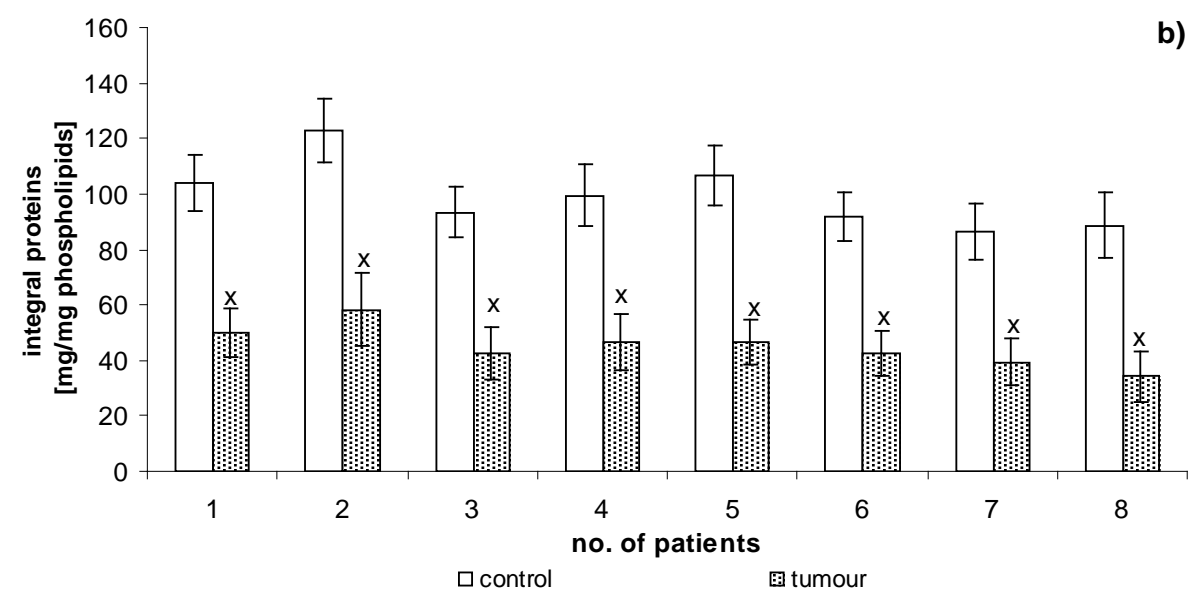

Figure 5. Content of peptides of hydrolyzed cell membranes in human renal cancer of pT3 stage, G3 grade with metastasis. Statistically significant differences for $p<0.05$. ${ }^{\mathrm{x}}$ In comparison with control. 


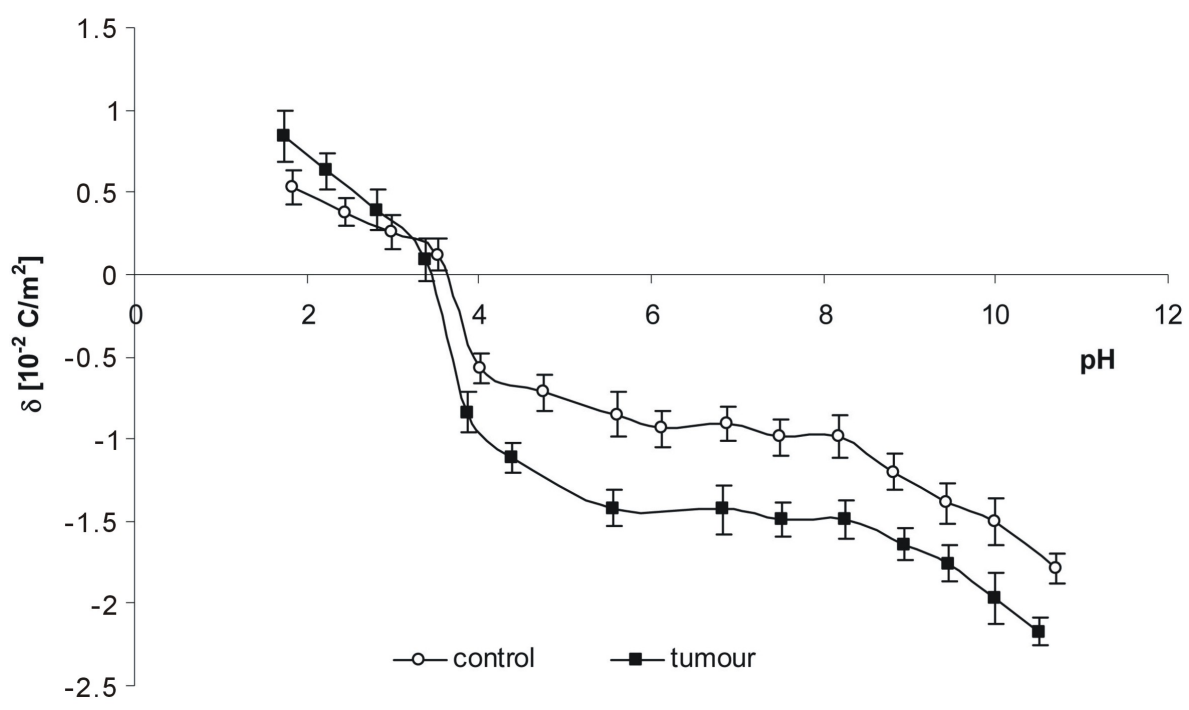

Figure 6. Dependence on $\mathrm{pH}$ of surface charge density of normal and renal cancer cells from several patients.

Table 1. Content of the amino acids Phe, Cys, Tyr and Arg for individual peptides following membrane protein hydrolysis of cell membranes in human renal cancer of pT3 stage, G3 grade with metastasis. Statistically significant differences for p < 0.05 . ${ }^{\mathrm{X}}$ In comparison with control.

\begin{tabular}{|c|c|c|c|c|c|c|c|}
\hline \multicolumn{8}{|c|}{ Concentration of amino acids (Phe, Tyr, Cys, Arg) } \\
\hline 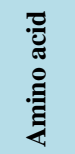 & 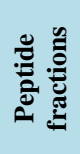 & Control & Tumour & 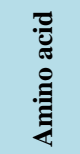 & 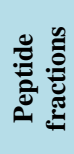 & Control & Tumour \\
\hline 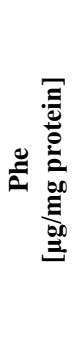 & $\begin{array}{c}6.2 \\
8.2 \\
9.1 \\
11.7 \\
12.6 \\
14.0 \\
17.1 \\
27.4 \\
28.9 \\
30.7 \\
\end{array}$ & $\begin{array}{l}2.61 \pm 0.53 \\
1.34 \pm 0.15 \\
1.65 \pm 0.22 \\
2.43 \pm 0.14 \\
2.73 \pm 0.17 \\
1.69 \pm 0.34 \\
1.71 \pm 0.33 \\
1.58 \pm 0.14 \\
2.85 \pm 0.56 \\
3.04 \pm 0.11\end{array}$ & $\begin{array}{c}1.97 \pm 0.49 \\
1.01 \pm 0.15^{\mathrm{x}} \\
1.18 \pm 0.12^{\mathrm{x}} \\
1.58 \pm 0.10^{\mathrm{x}} \\
2.15 \pm 0.10^{\mathrm{x}} \\
1.22 \pm 0.14 \\
1.16 \pm 0.22 \\
1.02 \pm 0.08^{\mathrm{x}} \\
1.83 \pm 0.37^{\mathrm{x}} \\
2.02 \pm 0.13^{\mathrm{x}}\end{array}$ & 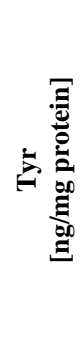 & $\begin{array}{c}6.2 \\
8.2 \\
9.1 \\
11.7 \\
12.6 \\
14.0 \\
17.1 \\
27.4 \\
28.9 \\
30.7\end{array}$ & $\begin{array}{l}0.26 \pm 0.03 \\
0.30 \pm 0.04 \\
0.21 \pm 0.01 \\
0.24 \pm 0.05 \\
0.30 \pm 0.02 \\
0.18 \pm 0.03 \\
0.28 \pm 0.05 \\
0.29 \pm 0.03 \\
0.19 \pm 0.06 \\
0.30 \pm 0.02\end{array}$ & $\begin{array}{c}0.18 \pm 0.02^{\mathrm{x}} \\
0.21 \pm 0.03^{\mathrm{x}} \\
0.13 \pm 0.07 \\
0.18 \pm 0.04 \\
0.21 \pm 0.02^{\mathrm{x}} \\
0.10 \pm 0.02 \\
0.24 \pm 0.04 \\
0.19 \pm 0.03^{\mathrm{x}} \\
0.14 \pm 0.05 \\
0.21 \pm 0.01^{\mathrm{x}}\end{array}$ \\
\hline 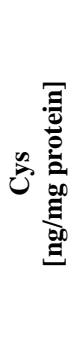 & $\begin{array}{c}6.2 \\
8.2 \\
9.1 \\
11.7 \\
12.6 \\
14.0 \\
17.1 \\
27.4 \\
28.9 \\
30.7\end{array}$ & $\begin{array}{l}40.3 \pm 9.38 \\
60.2 \pm 5.12 \\
42.0 \pm 2.31 \\
36.2 \pm 2.81 \\
33.0 \pm 6.07 \\
27.4 \pm 4.96 \\
37.5 \pm 2.68 \\
30.2 \pm 2.37 \\
28.4 \pm 3.54 \\
36.0 \pm 5.11\end{array}$ & $\begin{array}{c}31.8 \pm 7.21 \\
50.7 \pm 3.30^{\mathrm{x}} \\
26.2 \pm 1.99^{\mathrm{x}} \\
22.4 \pm 2.50^{\mathrm{x}} \\
25.5 \pm 5.34 \\
22.9 \pm 4.01 \\
23.4 \pm 4.11^{\mathrm{x}} \\
21.6 \pm 2.29^{\mathrm{x}} \\
20.5 \pm 3.09^{\mathrm{x}} \\
26.6 \pm 4.12^{\mathrm{x}}\end{array}$ & 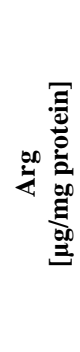 & $\begin{array}{c}6.2 \\
8.2 \\
9.1 \\
11.7 \\
12.6 \\
14.0 \\
17.1 \\
27.4 \\
28.9 \\
30.7\end{array}$ & $\begin{array}{l}9.10 \pm 0.52 \\
8.22 \pm 1.09 \\
5.88 \pm 1.49 \\
3.95 \pm 0.44 \\
4.96 \pm 0.55 \\
9.51 \pm 1.05 \\
4.17 \pm 0.48 \\
7.12 \pm 0.66 \\
4.03 \pm 0.61 \\
4.17 \pm 0.65\end{array}$ & $\begin{array}{c}6.72 \pm 0.21^{\mathrm{x}} \\
5.92 \pm 0.93^{\mathrm{x}} \\
3.67 \pm 1.26 \\
2.45 \pm 0.40^{\mathrm{x}} \\
3.24 \pm 0.35 \\
7.44 \pm 1.08 \\
2.70 \pm 0.40^{\mathrm{x}} \\
5.43 \pm 0.55^{\mathrm{x}} \\
2.09 \pm 0.30^{\mathrm{x}} \\
2.61 \pm 0.44^{\mathrm{x}}\end{array}$ \\
\hline
\end{tabular}

cells. The $\mathrm{C}_{\mathrm{TA}}, \mathrm{C}_{\mathrm{TB}}$ and $\mathrm{K}_{\mathrm{BOH}}$ values of cell membranes modified by cancer transformation were higher than in unmodified cells, while $\mathrm{K}_{\mathrm{AH}}$ decrease in comparison (Table 1). 
Table 2. $\mathrm{C}_{\mathrm{TA}}, \mathrm{C}_{\mathrm{TB}}, \mathrm{K}_{\mathrm{AH}}$ and $\mathrm{K}_{\mathrm{BOH}}$ of human renal cancer of pT3 stage, G3 grade with metastasis. Statistically significant differences for $\mathrm{p}<0.05$. ${ }^{\mathrm{x}} \mathrm{In}$ comparison with control.

\begin{tabular}{|c|c|c|c|c|c|}
\hline Patient No's & & $\begin{array}{c}\mathrm{C}_{\mathrm{TA}} \\
{\left[10^{-7} \mathrm{~mol} / \mathrm{m}^{2}\right]}\end{array}$ & $\begin{array}{c}\mathrm{C}_{\mathrm{TB}} \\
{\left[10^{-7} \mathrm{~mol} / \mathrm{m}^{2}\right]}\end{array}$ & $\begin{array}{c}\mathrm{K}_{\mathrm{AH}} \\
{\left[\mathrm{m}^{3} / \mathrm{mol}\right]}\end{array}$ & $\begin{array}{c}\mathrm{K}_{\mathrm{BOH}} \\
{\left[10^{7} \mathrm{~m}^{3} / \mathrm{mol}\right]}\end{array}$ \\
\hline \multirow{2}{*}{1.} & control & $1.19 \pm 0.09$ & $0.71 \pm 0.07$ & $45.80 \pm 0.92$ & $1.82 \pm 0.09$ \\
\hline & tumour & $1.74 \pm 0.10^{x}$ & $0.89 \pm 0.08^{x}$ & $31.61 \pm 1.02^{x}$ & $2.09 \pm 0.11^{\mathrm{x}}$ \\
\hline \multirow{2}{*}{2.} & control & $2.07 \pm 0.11$ & $0.77 \pm 0.09$ & $50.08 \pm 0.89$ & $2.02 \pm 0.11$ \\
\hline & tumour & $2.61 \pm 0.10^{x}$ & $1.16 \pm 0.08^{x}$ & $33.62 \pm 1.10^{\mathrm{x}}$ & $2.48 \pm 0.12^{x}$ \\
\hline \multirow{2}{*}{3.} & control & $1.71 \pm 0.10$ & $0.87 \pm 0.07$ & $42.18 \pm 1.10^{x}$ & $1.91 \pm 0.10^{\mathrm{x}}$ \\
\hline & tumour & $2.07 \pm 0.11^{x}$ & $0.93 \pm 0.06$ & $34.28 \pm 1.11^{\mathrm{x}}$ & $2.61 \pm 0.11^{\mathrm{x}}$ \\
\hline \multirow{2}{*}{4.} & control & $1.18 \pm 0.09$ & $0.95 \pm 0.09$ & $41.12 \pm 1.10^{x}$ & $1.62 \pm 0.09^{x}$ \\
\hline & tumour & $1.62 \pm 0.11^{\mathrm{x}}$ & $1.22 \pm 0.06^{\mathrm{x}}$ & $33.82 \pm 1.01^{x}$ & $2.14 \pm 0.10^{\mathrm{x}}$ \\
\hline \multirow{2}{*}{5.} & control & $2.03 \pm 0.10$ & $0.73 \pm 0.07$ & $38.32 \pm 0.95$ & $2.09 \pm 0.08$ \\
\hline & tumour & $2.31 \pm 0.10^{\mathrm{x}}$ & $0.92 \pm 0.08^{x}$ & $27.16 \pm 1.02^{x}$ & $2.31 \pm 0.10^{x}$ \\
\hline \multirow{2}{*}{6.} & control & $2.14 \pm 0.10$ & $0.69 \pm 0.07$ & $31.21 \pm 1.02$ & $1.93 \pm 0.07$ \\
\hline & tumour & $2.63 \pm 0.11^{x}$ & $0.95 \pm 0.05^{x}$ & $27.57 \pm 0.86^{x}$ & $2.16 \pm 0.08^{x}$ \\
\hline \multirow{2}{*}{7.} & control & $1.75 \pm 0.10$ & $0.59 \pm 0.05$ & $40.12 \pm 1.09$ & $1.96 \pm 0.09$ \\
\hline & tumour & $2.33 \pm 0.11^{\mathrm{x}}$ & $0.76 \pm 0.05^{x}$ & $31.23 \pm 1.07^{x}$ & $2.27 \pm 0.11^{\mathrm{x}}$ \\
\hline \multirow{2}{*}{8.} & control & $2.21 \pm 0.14$ & $0.74 \pm 0.06$ & $39.37 \pm 1.01$ & $1.71 \pm 0.07$ \\
\hline & tumour & $2.75 \pm 0.16^{\mathrm{x}}$ & $0.99 \pm 0.08^{x}$ & $29.24 \pm 0.90^{x}$ & $2.01 \pm 0.10^{x}$ \\
\hline
\end{tabular}

\section{Discussion}

Kidney tissue is particularly susceptible to reactive oxygen species attack which leads to development of cancer. During oxidative stress, membrane lipids and proteins are major targets of reactive oxygen species (ROS). The convergent mechanisms dependent on ROS may explain a role in the process of carcinogenesis.

One hypothesis is that mediators of the effects of ROS may lie in the initiation of the formation of oxidation products including those derived from lipid peroxidation [16]. For example, the generation of 4-hydroxy-2nonenal (HNE), which is one of the final products of lipid peroxidation, has been observed in an experimental animal model of renal carcinoma [17] [18]. HNE is highly electrophilic molecule, which predisposes it to localize in the cell membranes. It can easily react with low molecular weight compounds, such as glutathione, with proteins and lipids [19] [20]. HNE has been shown to form Michael adducts via the C-3 atom with the sulfydryl group of Cys residues [21]. Recently, it has been proposed that HNE can also modify Arg residues of proteins [22]. Other amino acids are also susceptible to attack by free radicals. The aromatic amino acids, such as phenylalanine (Phe) and tyrosine (Tyr) are most sensitive to oxidation. Phe can be converted into Tyr [23]. Moreover, the nitration of tyrosine residues in various proteins has been shown to inhibit their functions [24]. The occurrence of these types of reactions corresponds with a decrease in the number of Phe, Tyr, Cys and Arg in renal cancer detected in our study relative to the unmodified cells (Table 1 ).

The ultimate consequence of cancer transformation-induced protein modifications can include structural changes, such as aggregation or fragmentation [25] [26]. The results presented herein indicate that structural changes in protein molecules following cancer transformation are characterized by fragmentation rather than by aggregation because they are more susceptible to proteolysis. Protein fragmentation can generate new functional groups, both acidic and basic. These changes can yield higher negative electric charge at high $\mathrm{pH}$ values and lower positive electric charges at low $\mathrm{pH}$ values, as described previously [6].

The decrease in the levels of integral proteins in renal cell membrane may in turn lead to an increase in the levels of other charged molecules on the cell surface, such as phospholipids. Our previous experiments demonstrated that the cell membrane and the function are modified during cancer transformation. It is reflected by changes in the amount of phospholipids of human renal cell membrane [1]. The results of our research confirm the increase in the levels of phospholipids of renal cancer cell membrane relative to the unmodified cells (Figure 3). The amounts of phospholipids presented in this Figure also show that the content of phosphatidylcholine in normal human kidney and human kidney cancers is higher than that of other phospholipids. Its 
amount is higher in cancer cells. The higher amount of phospholipids can be due to enhanced cell membrane synthesis related to accelerated neoplasm cell replication [1]. The mechanisms which are responsible for an increase in the amount of phospholipids can vary depending on cell nature, cell growth phase and its malignancy.

Increased amount of phospholipids results in a higher amount of functional groups: amino, carboxy and phosphate groups. In acid medium (low $\mathrm{pH}$ ), the charge of phospholipids is mainly due to amino groups whereas in basic medium (high $\mathrm{pH}$ ) it is due to carboxy and phosphate groups. Increased amount of phospholipids can increase surface density of negatively charged groups of renal cancer cell membrane at low $\mathrm{pH}$ values and that of positively charged ones at high $\mathrm{pH}$; it has been confirmed by the results of this work (Figure 6, Table 2). The main component of the renal cancer cell membrane outer layer is phosphatidylcholine and its higher content can provoke an increase in both positively charged groups concentration at low $\mathrm{pH}$ values and in negatively charged groups concentration at high $\mathrm{pH}$ values.

The cell membrane charge is also affected by sialic acid being the component of glycolipids and glycoproteins. Sialylation affects the half-lives of many circulating glycoproteins and plays roles in a variety of biologic processes such as cell-cell communication, cell-matrix interaction, adhesion and protein targeting [27]. It has been supposed that sialic acid also influences surface concentration of acid and basic groups as well as association constants of positive and negative groups during cancer transformation.

\section{Conclusion}

To sum up, the renal cell membrane structure and function are modified by neoplasm lesion. It is reflected by changes in the amount of proteins, phospholipids and in the electric charge of human kidney cell membrane.

\section{Acknowledgements}

The research was supported by the Medical University of Białystok (grant AMB: 123-61686L).

\section{References}

[1] Szachowicz-Petelska, B., Dobrzyńska, I., Skrodzka, M., Darewicz, B., Figaszewski, Z.A. and Kudelski, J. (2013) Phospholipid Composition and Electric Charge in Healthy and Cancerous Parts of Human Kidneys. Journal of Membrane Biology, 246, 421-425. http://dx.doi.org/10.1007/s00232-013-9554-7

[2] Szachowicz-Petelska, B., Sulkowski, S. and Figaszewski, Z. (2007) Altered Membrane Free Unsaturated Fatty Acid Composition in Human Colorectal Cancer Tissue. Molecular and Cellular Biochemistry, 294, 237-242. http://dx.doi.org/10.1007/s11010-006-9264-x

[3] Field, C.J., Thomson, C.A., van Aerde J.E., et al. (2000) Lower Proportion of CD45R0+ cells and Deficient Interleukin-10 Production by Formula-Fed Infants, Compared with Human-fed, is Corrected with Supplementation of LongChain Polyunsaturated Fatty Acids. Journal of Pediatric Gastroenterology and Nutrition, 31, 291-299. http://dx.doi.org/10.1097/00005176-200009000-00017

[4] de Pablo, M.A. and Alvarez, D.C. (2000) Modulatory Effects of Dietary Lipids on Immune System Functions. Immunology and Cell Biology, 78, 31-39. http://dx.doi.org/10.1046/j.1440-1711.2000.00875.x

[5] Szachowicz-Petelska, B., Dobrzyńska, I., Figaszewski, Z. and Sulkowski, S. (2002) Changes in Physico-Chemical Properties of Human Large Intestine Tumour Cells Membrane. Molecular and Cellular Biochemistry, 238, 41-47. http://dx.doi.org/10.1023/A:1019946718876

[6] Dobrzyńska, I., Szachowicz-Petelska, B., Sulkowski, S. and Figaszewski, Z.A. (2005) Changes in Electric Charge and Phospholipids Composition in Human Colorectal Cancer Cells. Molecular and Cellular Biochemistry, 276, 113-119. http://dx.doi.org/10.1007/s11010-005-3557-3

[7] Szachowicz-Petelska, B., Sulkowski, S. and Figaszewski, Z.A. (2012) Altered Membrane Amino Acids Composition in Human Colorectal Cancer Tissue. Central European Journal of Chemistry, 10, 1245-1252. http://dx.doi.org/10.2478/s11532-012-0050-1

[8] Ipata, P.L. (1967) A Coupled Optical Enzyme Assay for 5'-Nucleotidase. Analytical Biochemistry, 20, 30-36. http://dx.doi.org/10.1016/0003-2697(67)90261-8

[9] Evans, W.H. (1970) Fractionation of Liver Plasma Membranes Prepared by Zonal Centrifugation. Biochemistry Journal, 166, 833-842.

[10] Folch, J., Lees, M. and Stanley, G.H.S. (1957) A Simple Method for the Isolation and Purification of Total Lipids from Animal Tissues. Journal of Biological and Chemistry, 226, 497-509.

[11] Tani, H., Kamidate, T. and Watanabe, H. (1997) Micelle-Mediated Extraction. Journal of Chromatography A, 780, 
229-241. http://dx.doi.org/10.1016/S0021-9673(97)00345-2

[12] Persaud, D.R., Persaud, D.G., Dalgleish, L., Nadeau, L. and Gauthier, S. (2000) Isolation and Purification of Serum and Interfacial Peptides of a Trypsinolyzed Beta-Lactoglobulin Oil-In-Water Emulsion. Journal of Chromatography B: Biomedical Sciences and Applications, 744, 389-397. http://dx.doi.org/10.1016/S0378-4347(00)00266-8

[13] Krysiński, P. and Tien, H.Y. (1986) Membrane Electrochemistry. Progress in Surface Science, 23, 317-412. http://dx.doi.org/10.1016/0079-6816(86)90016-X

[14] Barrow, G.M. (1996) Physical Chemistry. McGraw-Hill Pocket Books, New York.

[15] Dobrzyńska, I., Skrzydlewska, E. and Figaszewski, Z.A. (2006) Parameters Characterizing Acid-Base Equilibria between Cell Membrane and Solution and Their Application to Monitoring the Effect of Various Factors on the Membrane. Bioelectrochemistry, 69, 142-147. http://dx.doi.org/10.1016/j.bioelechem.2006.01.004

[16] Takabe, W., Niki, E., Uchida, K., Yamada, S., Satoh, K. and Noguchi, N. (2001) Oxidative Stress Promotes the Development of Transformation: Involvement of a Potent Mutagenic Lipid Peroxidation Product, Acrolein. Carcinogenesis, 22, 935-941. http://dx.doi.org/10.1093/carcin/22.6.935

[17] Toyokuni, S., Uchida, K., Okamato, K., Hattori-Nakakui, Y., Hiai, H. and Stadtman, E.R. (1994) Formation of 4-Hydroxy-2-Nonenal-Modified Proteins in the Renal Proximal Tubules of Rats Treated with a Renal Carcinogen, Ferric Nitrilotriacetate. Proceedings of the Naional Academy of Sciences of the United States of America, 91, 2616-2620. http://dx.doi.org/10.1073/pnas.91.7.2616

[18] Uchida, K., Fukuda, A., Kawakishi, S., Hiai, H. and Toyokuni, S. (1995) A Renal Carcinogen Ferric Nitrilotriacetate Mediates a Temporary Accumulation of Aldehydes-Modified Proteins within Cytosolic Compartment of Rat Kidney. Archives of Biochemistry and Biophysics Arch, 317, 405-411. http://dx.doi.org/10.1006/abbi.1995.1181

[19] Uchida, K. (2003) 4-Hydroksy-2-Nonenal: A Product and Mediator of Oxidative Stress. Progress in Lipid Research, 42, 318-343. http://dx.doi.org/10.1016/S0163-7827(03)00014-6

[20] Pizzimenti, S., Toaldo, C., Pettazzoni, P., Ciamporcero, E., Dianzani, M.U. and Barrera, G. (2012) Lipid Peroxidation in Colorectal Carcinogenesis: Bad and Good News. In: Rajunor, E., Ed., Colorectal Cancer Biology, InTech, 155-172.

[21] Esterbauer, H., Schaur, R.J. and Zollner, H. (1991) Chemistry and Biochemistry of 4-Hydroxynonenal, Malonaldehyde and Related Aldehydes. Free Radical Biology and Medicine, 11, 81-128. http://dx.doi.org/10.1016/0891-5849(91)90192-6

[22] Isom, A.L., Barnes, S., Wilson, L., Kirk, M., Coward, L. and Darley-Usmar, V. (2004) Modification of Cytochrome c by 4-Hydroxy-2-Nonenal Evidence for Histidine, Lysine and Arginine-Aldehyde Adducts. The Journal of the American Society for Mass Spectrometry, 15, 1136-1147. http://dx.doi.org/10.1016/j.jasms.2004.03.013

[23] Boirie, Y., Albright, R., Bigelow, M. and Nair, K.S. (2004) Impairment of Phenylalanine Conversion to Tyrosine Inend-Stage Renal Disease Causing Tyrosine Deficiency. Kidney International, 66, 591-596. http://dx.doi.org/10.1111/j.1523-1755.2004.00778.x

[24] Gius, D. (2004) Redox-Sensitive Signaling Factors and Antioxidants: How Tumor Cells Respond to Ionizing Radiation. American Society for Nutritional Sciences, 134, 3213S-3214S.

[25] Gabai, V.L., Kabakov, A.E., Makarova, I.M., Mosina, V.A. and Mosin, A.F. (1994) Fragmentation of Ehrlich Ascites Carcinoma DNA during Influences Causing Aggregation of Cytoskeletal Proteins. Biokhimiia, 59, 551-558.

[26] Rantanen, K., Pursiheimo, J., Högel, H., Himanen, V., Metzen, E. and Jaakkola, P.M. (2008) Prolyl Hydroxylase PHD3 Activates Oxygen-Dependent Protein Aggregation. Molecular Biology of the Cell, 19, 2231-2240. http://dx.doi.org/10.1091/mbc.E07-11-1124

[27] Wang, P.H. (2005) Altered Glycosylation in Cancer: Sialic Acids and Sialyltransferases. Journal of Cancer Molecules 1, 73-81. 